Volume 10, Issue 2 (Summer 2018)

\title{
Bernard Lens's Miniatures for the Duke and Duchess of Marlborough
}

Marjorie E. Wieseman

BWieseman@clevelandart.org

Recommended Citation:

Marjorie E. Wieseman, "Bernard Lens's Miniatures for the Duke and Duchess of Marlborough," Journal of Historians of Netherlandish Art 10:2 (Summer 2018) DOI: 10.5092/jhna.2018.10.2.3 Available at https://jhna.org/articles/bernard-lenss-miniatures-for-the-duke-and-duchess-ofmarlborough/

Published by Historians of Netherlandish Art: https://hnanews.org/

Republication Guidelines: https://jhna.org/republication-guidelines/

Notes: This PDF is provided for reference purposes only and may not contain all the functionality or features of the original, online publication. This PDF provides paragraph numbers as well as page numbers for citation purposes.

ISSN: 1949-9833 


\title{
Bernard Lens's Miniatures for the Duke and Duchess of Marlborough
}

\author{
Marjorie E. Wieseman
}

Using Bernard Lens III's small-scale gouache on vellum copy after Rubens, His Wife Helena Fourment, and Their Son Frans as a point of departure (both paintings are in the collection of the Metropolitan Museum of Art in New York), the present article examines the English tradition of small-scale copies and the particular collecting habits of the eighteenth-century owners of Rubens's painting, John and Sarah Jenyns Churchill, first Duke and Duchess of Marlborough. Working for the Marlboroughs and other prominent collectors of the era, Lens painted miniature copies after some of the most important paintings in their collections as well as miniature portraits of family members. The article suggests possible motivations for these commissions and for the selection of particular works for copying.

1 It is difficult to identify an object in the collections of the Metropolitan Museum of Art with connections to Dutch or Flemish painting that managed to escape Walter Liedtke's keen eye, meticulous scholarship, and sly wit. Yet there is one among the lesser-known works in the European Paintings Department: a large and colorful miniature copy on vellum of Rubens, His Wife Helena Fourment, and Their Son Frans, painted in 1721 by Bernard Lens III (1682-1740) (fig. 1). ${ }^{1}$ Acquired by the museum primarily for its documentary relationship to the original (and a few years after the publication of Liedtke's Flemish Paintings in the Metropolitan Museum of Art), Lens's miniature hardly achieves the voluptuousness and deftness of touch that characterize Rubens's masterwork of the late 1630s (fig. 2). Yet its clear colors and graphic fidelity are useful for elucidating details in the oil painting that have become less evident over time, and its mere existence provokes questions about how and why such a work was created. In 1986, prompted by a smallscale copy of a Rubens painting that had recently been acquired by the Yale Center for British Art, Ann-Marie Logan presented a wealth of information on Lens's miniature copies after Rubens and Anthony van Dyck (including the present work). ${ }^{2}$ The present essay expands upon those findings to consider Lens's copy of Rubens, His Wife Helena Fourment, and Their Son Frans in the context 


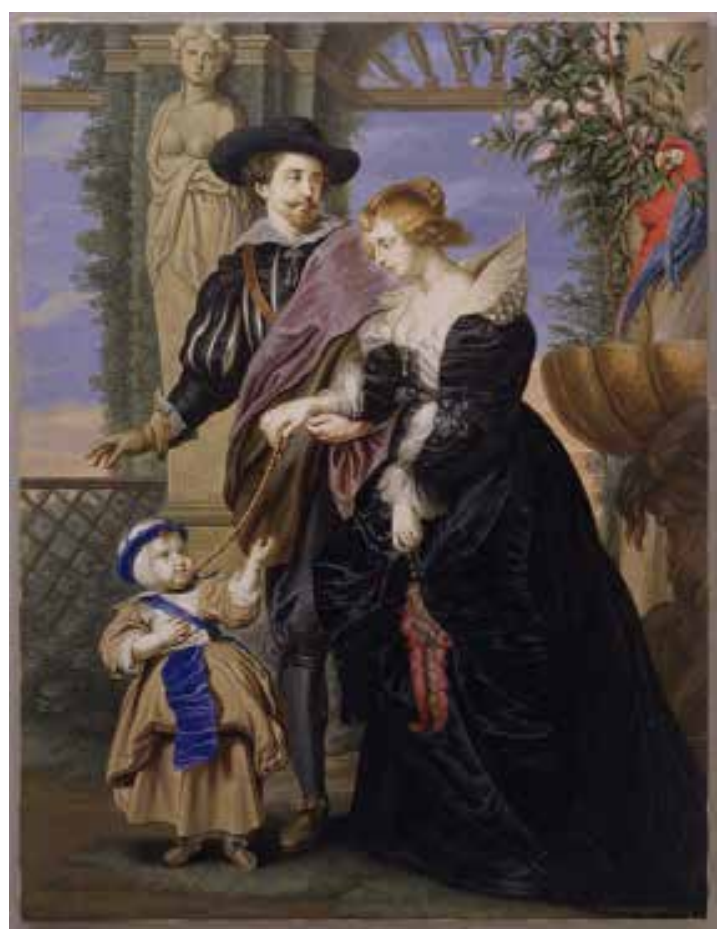

Fig. 1 Bernard Lens III, Rubens, His Wife Helena Fourment, and Their Son Frans, 1721, watercolor and bodycolor on vellum, 394 × 302 mm. New York, The Metropolitan Museum of Art, inv. 1984.442 (artwork in the public domain)

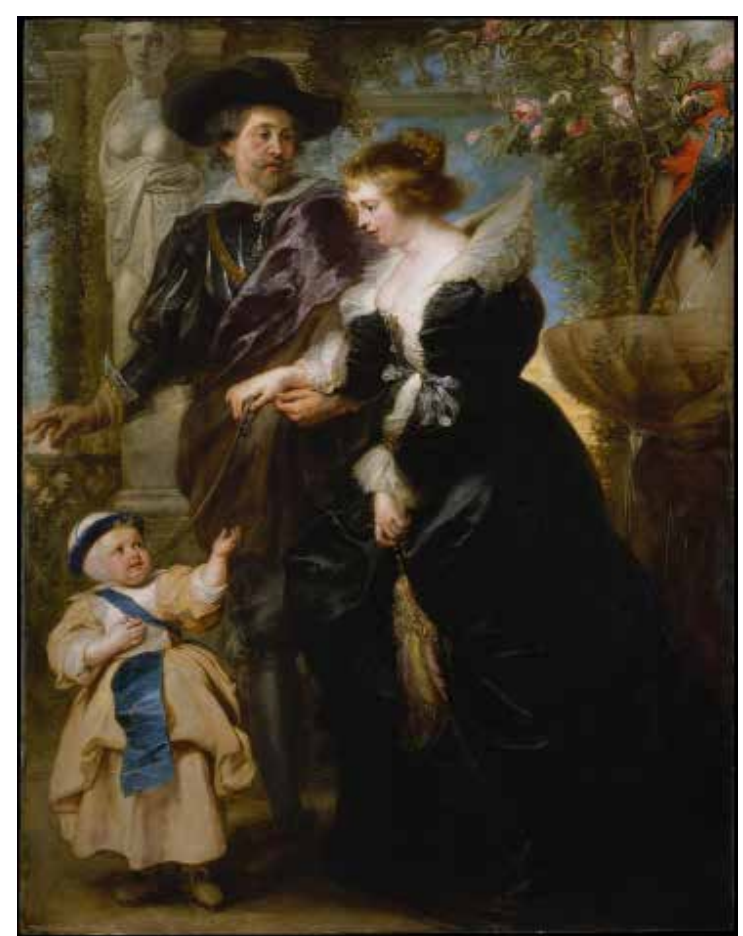

Fig. 2 Peter Paul Rubens, Rubens, His Wife Helena Fourment, and Their Son Frans, ca. 1635, oil on wood, 203.8 x $158.1 \mathrm{~cm}$. New York, The Metropolitan Museum of Art, inv. 1981.238 (artwork in the public domain)

of the English tradition of small-scale copies and the artistic aspirations of the eighteenth-century owners of Rubens's painting, John and Sarah Jenyns Churchill, first Duke and Duchess of Marlborough, who sanctioned Lens's copy.

2 John Churchill (1650-1722) achieved swift military and political advancement in service to James, Duke of York, and was instrumental in bringing him to the throne as James II of England in 1685. Churchill soon switched allegiance to the Protestant Prince William of Orange, and shortly after William's accession to the throne (as William III) in 1688, was created Earl of Marlborough. In 1701, Marlborough was appointed commander-in-chief of the English army in Holland and led the allied forces against France in the War of the Spanish Succession. A string of spectacular victories - at Blenheim, Ramilles, Oudenaerde, and elsewhere-sealed Marlborough's renown. Under the patronage of Queen Anne, whose most intimate friend and Mistress of the Robes was Churchill's wife, Sarah Jenyns (1660-1744), the Marlboroughs' fortune, power, and influence rose astronomically. The queen made Marlborough a duke and granted him the manor of Woodstock as reward for his victory at Blenheim. Parliament approved substantial funds toward the creation of a home suitable for a national hero: Blenheim Palace. Construction on the vast palace, designed by Sir John Vanbrugh and completed by Nicolas Hawksmoor, was hampered by a variety of factors and was only completed in the 1730s, more than a decade after the duke's death. Yet throughout the long years of building works, the Marlboroughs' correspondence demonstrates that they both took close interest in furnishing the house and buying or commissioning art to fill it. The duke in particular took advantage of his military duties on the Continent to order tapestries and acquire paintings he especially admired: "I am so fond of some pictures I 
shall bring with me, that I could wish you had a place for them until the Gallery at Woodstock be finished; for it is certain there are not in England so fine pictures as some of these, particularly the King Charles on horseback, done by Vandyke." ${ }^{3}$ The Marlboroughs were especially drawn to the work of Peter Paul Rubens and eventually owned at least twenty paintings by or attributed to him. A taste for Old Masters did not cause them to neglect contemporary English artists, and they also commissioned works from (among others) Godfrey Kneller, John Closterman, Grinling Gibbons, the French-born Louis Laguerre, James Thornhill, and Michael Rysbrack.

3 Another English artist patronized by the duke and duchess was the peripatetic miniature painter and copyist Bernard Lens III. Lens was the son of Bernard Lens II (1659/60-1725), draftsman and drawing master at Christ's Hospital, London. ${ }^{4}$ The younger Lens was also a prolific draftsman (the works of father and son are often confused) and drawing master who counted among his pupils Horace Walpole, three children of King George II (William Augustus, Mary, and Louisa), and John Spencer, grandson of the first Duke of Marlborough. ${ }^{5}$ In 1720 Lens was appointed "Painter in Enamell [sic] in Ordinary" to King George I (an unsalaried position, according to George Vertue), and after the king's death in 1727 served his successor George II in the same capacity. This official title was somewhat of a misnomer, as Lens never worked in enamel: Vertue notes that his predecessor in the post, Charles Boit (1662-1727), had caused the honorary designation to be changed from "Limner" to "Enameller" to reflect his own talents, and the title was simply transferred to Lens. It is as a painter of miniatures that Lens is best remembered: his earliest dated portrait miniature (Portrait of Dr. Harris, 1707; New Haven, Yale Center for British Art, inv. B1974.2.66) is the first dated miniature to be painted in Britain on ivory, rather than the traditional support of vellum. Lens continued to paint original likenesses throughout his career, but he also had a thriving business limning copies of historic miniatures and miniature copies on paper or vellum of oil paintings in prestigious collections by both Old Masters and contemporary artists.

The small-scale reproduction of oil paintings through the medium of watercolor and gouache on vellum (often called "cabinet miniatures") had a respected history in Britain: producing copies was one of the traditional purposes of the office of king's limner. ${ }^{6}$ Isaac Oliver (1560/5-1617) was perhaps the first English artist to paint religious and historical cabinet miniatures for the royal family; later in the seventeenth century, Richard Gibson, David Des Granges, and Nicholas Dixon all painted subject pieces alongside more traditional portrait miniatures. Between 1628 and the late 1630s, Isaac's son Peter Oliver (ca. 1689-1647) made at least ten miniature copies for King Charles I of some of the most highly valued paintings in his collection. ${ }^{7}$ The enormous amount of time and effort involved in making these detailed copies made them immensely costly, and artists often maximized their investment by making a second version to keep for themselves or to sell to another patron. ${ }^{8}$ By the early eighteenth century the production of small-scale copies after oil paintings had become a veritable industry, and while they were still expensive, they were no longer the sole preserve of royalty.

A number of Bernard Lens's copies reproduce historic sixteenth- and seventeenth-century portrait miniatures, including a series of likenesses of kings and queens of England, many of which survive in multiple examples. ${ }^{9}$ These tend to be somewhat crudely executed and were probably made for sale on the open market. Lens also painted miniature likenesses of writers, philosophers, and artists-among the latter, Rubens, Raphael, and van Dyck were honored alongside home- 
grown talents such as Samuel Cooper, William Dobson, and John Greenhill—copied either from older miniatures or from full-sized paintings. Catering to a slightly more sophisticated taste, these are perhaps more likely to have been done on commission. ${ }^{10}$ The finest of Lens's copies, however-and what he was best known for in his lifetime-were his reproductions of large-scale oil paintings. Contemporaries like Horace Walpole especially praised his ability to capture the vivid colors of the original oil paintings in these small watercolors on vellum or paper. ${ }^{11}$ Lens's copies tend to be quite accurate and demonstrate a keen awareness of the strengths and limitations of his chosen medium. While the inherent properties of oil paint allowed for softly blended and suggestive passages, gouache required Lens to either greatly simplify these areas of the composition (for example, in backgrounds) or describe them in precise detail (such as foreground foliage). He occasionally added touches of gold for highlights and/or his signature or monogram.

Lens's most serious rival in this field was the Huguenot artist Joseph Goupy (1689-1769), who painted copies after predominantly Italian artists (Raphael, Salvator Rosa, Poussin, Titian, Luca Giordano, van Dyck, etc.) for his aristocratic patrons. In 1736 Goupy was named Cabinet Painter to Frederick, Prince of Wales. ${ }^{12}$ While Goupy made his career copying Italian masters almost exclusively, Lens divided his time between painting portraits from life and painting cabinet miniatures reproducing works by a range of French, Flemish, Italian and British artists.

Logan identified five cabinet miniatures by Lens after paintings by Rubens and van Dyck, including the copy of Rubens, His Wife Helena Fourment, and Their Son Frans now in the Metropolitan Museum. ${ }^{13}$ Many more works can be added to this core group. While the resulting list is surely far from complete, it does give a better perspective on Lens's activities in this area. Several of Lens's cabinet miniatures can be connected with the Duke and Duchess of Marlborough, but he also worked for other prestigious collectors, such as James Brydges, first Duke of Chandos (16731744); Robert Harley, later first Earl of Oxford and his son Edward, later second Earl of Oxford (1689-1741); John Hervey, first Earl of Bristol (1665-1751); Dr. Richard Mead (1673-1754); Sir Paul Methuen (ca. 1672-1757); and Sir Robert Walpole, first Earl of Orford and first Prime Minister of England (1676-1745). Lens offered his clients a variety of services: original miniature likenesses on ivory and cabinet miniatures reproducing larger works, as well as drawing lessons and advice on framing. ${ }^{14}$ Edward Harley (a noted collector of books, manuscripts, coins, medals, and miniatures) had received drawing lessons from Lens's father (Bernard II) beginning in 1707. This connection paved the way for the younger Lens to undertake a number of commissions for Harley between 1714 and 1728, including miniature copies of family portraits by Kneller and Michael Dahl, a portrait of Matthew Prior on vellum "after a French pictor," and a detailed copy of Livinius de Vogelaar's Memorial of Lord Darnley, then in the collection of Thomas Fermor, first Earl of Pomfret. ${ }^{15}$ For John Hervey, Lens painted eight miniature copies of portraits (all of artists, with the exception of a likeness of Isaac Newton) and a copy after a Madonna and Child at Kensington Palace, then thought to be by Raphael. ${ }^{16}$

In the case of other cabinet miniatures, it is unclear whether they were commissioned by the owners of the full-scale original or whether they were made by Lens for his own use. In 1713, the Duke of Chandos commissioned Lens to make a copy (or copies) from Godfrey Kneller's portrait of himself together with his wife and two sons. ${ }^{17} \mathrm{~A}$ few years later, in 1719, Lens painted a cabinet miniature reproducing one of the most renowned paintings in the duke's collection, Poussin's 
Choice of Hercules $;{ }^{18}$ in this instance, however, there is no record of a commission and the copy evidently remained in the artist's possession..$^{19}$ It is therefore difficult to draw broad conclusions about the original purpose, intended owner, or display location for Lens's cabinet miniatures. The auction held by Christopher Cock in London in February 1737 of "the entire and elaborate works of Mr Bernard Lens, limner to their present Majesties; consisting of many excellent limnings, by him copied from the most famous pictures now in royal and other celebrated collections in England" included approximately sixty copies by Lens after other masters, suggesting that the artist had retained many of these highly detailed and labor-intensive works for himself, or for the enrichment of his pupils. ${ }^{20}$ It is also possible-but perhaps less likely, given that few if any are known in multiple autograph examples-that the sale lots represent a second copy made for personal use or eventual sale to a client who might desire to own a reduced version of a famous painting housed in a renowned collection. The descriptions in the auction catalogue, while brief, often mention the name of the owner of the original, details likely gleaned from the extensive inscriptions found on the reverse of many of Lens's extant miniatures and included as added enticement for would-be buyers.

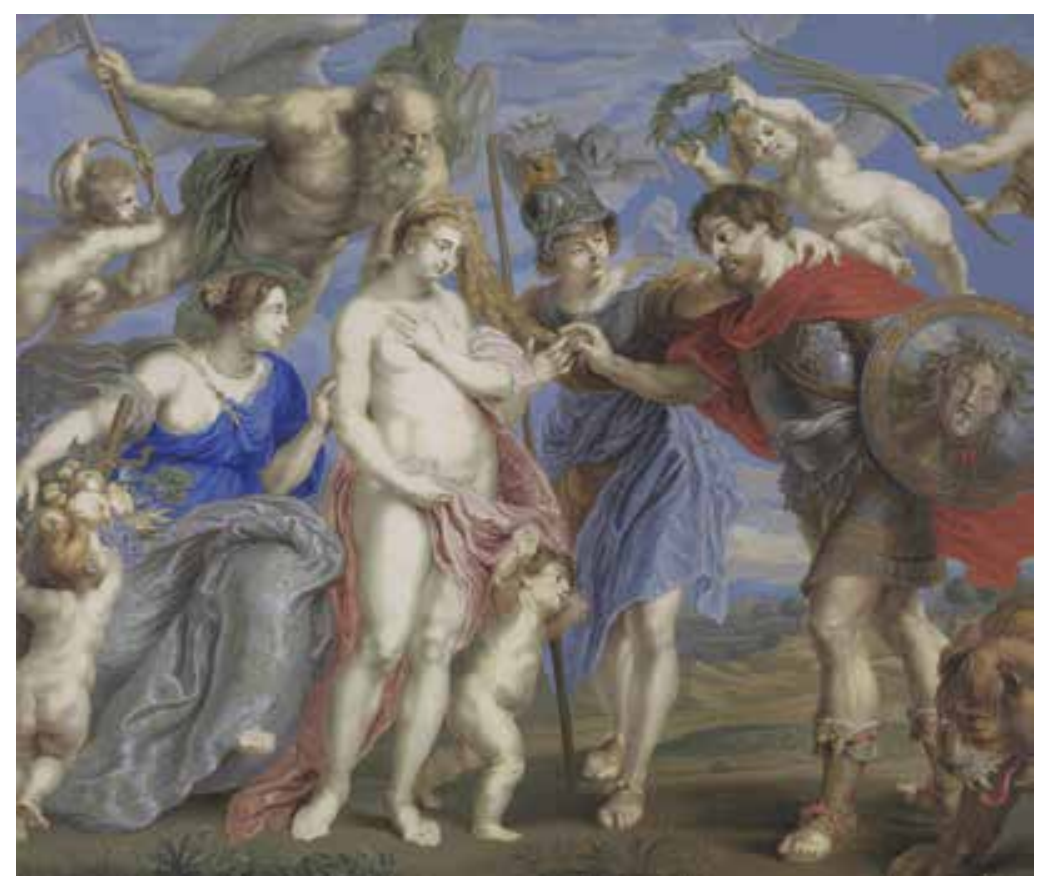

Fig. 3 Bernard Lens III, The Victorious Hero Takes Occasion to Conclude Peace, 1720, watercolor and gouache, heightened with gold, on vellum, $394 \mathrm{x}$ $476 \mathrm{~mm}$. New Haven, Yale Center for British Art, inv. B1982.6 (artwork in the public domain)

Dated works by Lens for the Duke and Duchess of Marlborough indicate that he worked most actively for them between 1720 and 1722, although he may have painted miniature portraits of the family earlier and certainly continued his connection with them after. ${ }^{21}$ In 1720, Lens made the first of his cabinet miniatures after a seventeenth-century Flemish painting in the Marlborough collection: The Victorious Hero Takes Occasion to Conclude Peace (fig. 3), after a painting by Rubens now known via a workshop version at Siegen; ${ }^{22}$ and King Charles I on Horseback, after the original by van Dyck now in the National Gallery, London (figs. 4, 5). The miniatures are precisely dated: July 21, 1720, and August 12, 1720, respectively, suggesting, perhaps, that the artist took up a summer residency at Blenheim in order to copy the paintings. He also made several likenesses of family members, ranging from small (original) oval likenesses in watercolor on ivory ${ }^{23}$ to larger cabinet miniatures reproducing full-sized oil paintings: portraits of Sarah Churchill, Duchess of 


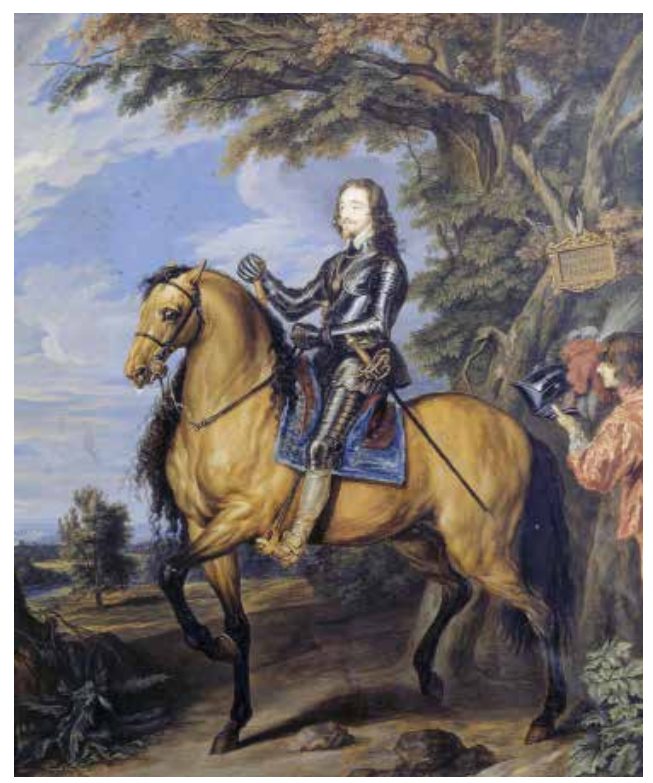

Fig. 4 Bernard Lens III, King Charles I on Horseback, 1721, gouache on vellum, $483 \times 413 \mathrm{~mm}$. Croft Castle, Herefordshire, Midlands (National Trust), inv. NT 537591 (artwork in the public domain)

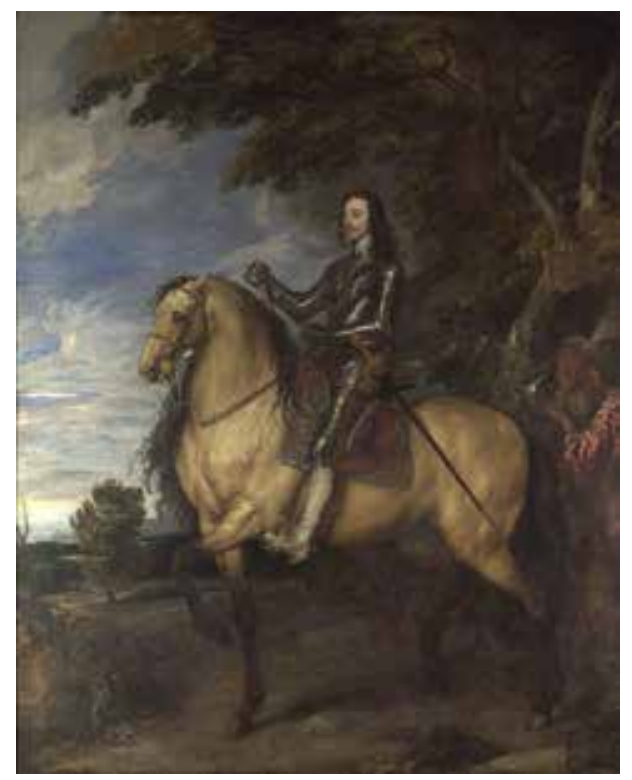

Fig. 5 Anthony van Dyck, King Charles I on Horseback, ca. 1638, oil on canvas, approx. $367 \times 292.1 \mathrm{~cm}$. London, The National Gallery, inv. NG1172 (artwork in the public domain)

Marlborough (fig. 6), and of her daughter Anne, Countess of Sunderland, with her son, both after Kneller. ${ }^{24}$ More unusual are "hybrid" portraits of family members, which reworked compositions by van Dyck to accommodate modern likenesses: a portrait of the Countess of Sunderland's three youngest children, based on van Dyck's Portrait of the Three Eldest Children of Charles I, ${ }^{25}$ and an adaptation of van Dyck's Portrait of Charles I that substitutes the head of the Duke of Marlborough for that of the monarch. ${ }^{26}$ The miniature equestrian portrait of the duke, as well as that of his wife after Kneller, are again precisely dated: November 12, 1720, and December 31, 1720, respectively, and an inscription on the latter indicates that it was done in London. Both also note that they were done "ad vivum"- presumably in the presence of the subjects themselves (and not necessarily the original paintings) during their winter residence in town.

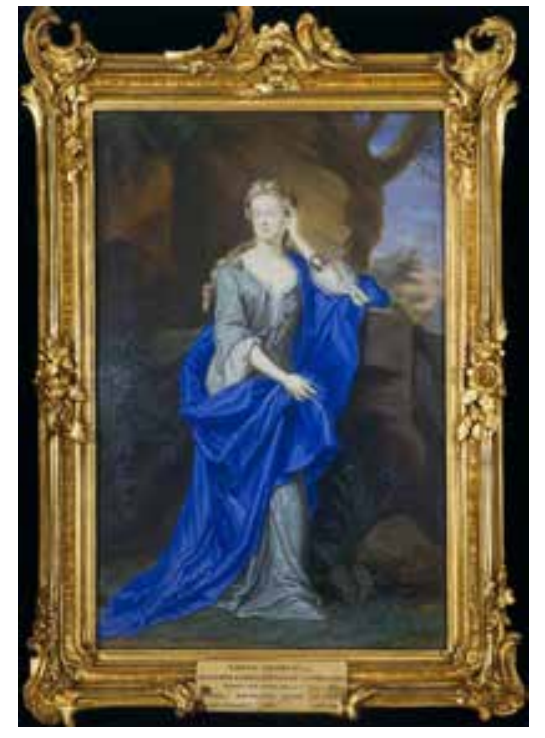

Fig. 6 Bernard Lens III, Sarah Churchill, Duchess of Marlborough, 1720, watercolor on vellum, approx. 405 × $260 \mathrm{~mm}$. London, Victoria and Albert Museum, inv. 627-1882 (artwork in the public domain) 
In 1721 Lens painted a further two copies after Flemish paintings in the Marlborough collection: the Rubens, His Wife Helena Fourment, and Their Son Frans and a copy of a Madonna and Child by van Dyck, which again is precisely annotated "from the original by Sir Anthony Van Dyck / and with the leave of the Duke of Marlborough at Blenheim Castle near Woodstock in Oxfordshire June 6th 1721."27 In the same year Lens painted a copy after Paolo Veronese's Dream of Saint Helena, which was then probably in the collection of the duke's son-in-law, Francis, second Earl of Godolphin. ${ }^{28}$ The last dated cabinet miniature Lens produced for the Marlboroughs was painted in 1722, the year of the duke's death. On January 19, the Duchess of Marlborough purchased a version of Rubens's Roman Charity at the sale of the Duke of Portland's collection for the substantial amount of 500 guineas ( $£ 525)$; Lens’s copy of the work is dated March 28, 1722. ${ }^{29}$ There are at least two further miniature copies by Lens after Flemish paintings in the Marlborough collection, for which no dates have been recorded: The Three Graces, after a version of the painting by Rubens in the Museo del Prado, Madrid; and Time Clipping Cupid's Wings, after the original by van Dyck now in the Musée Jacquemart-André, Paris. In the 1720s Vertue described the original painting by van Dyck as hanging "at Marlborough house" (the London residence of the Duchess of Marlborough) and noted "this picture is copyd by Mr Lens." ${ }^{0}$

11 The Marlboroughs' willingness to commission (or at least allow) Lens to paint small-scale copies of key paintings in their collection may have been inspired by a group of works already in their possession: namely 126 of David Teniers the Younger's small copies (pasticci) of Italian paintings from the collection of the Hapsburg Archduke Leopold Wilhelm. These had been made in the mid-1650s as modelli for engraved illustrations in the magnificent catalogue of the archduke's collection, the Theatrum Pictorium, published in $1660 .{ }^{31}$ It is not clear when or where Marlborough acquired Teniers's copies; he visited Brussels on several occasions between 1706 and 1708 and is known to have arranged to have a number of paintings (including the Rubens, His Wife Helena Fourment, and Their Son Frans) "donated" to him on these visits, in recognition of his military service in the Southern Netherlands. It is possible that Teniers's copies may have been part of such a gift, culled from one of the local residences of the former Spanish Hapsburg governors. ${ }^{32}$ The paintings are first recorded in the Marlborough collection in 1728; ${ }^{33}$ the 1740 inventory of furnishings at Blenheim Palace dictated by Sarah, Duchess of Marlborough, describes them as hanging in the Long Closet (a small room adjacent to her dressing room): "Lesser Pictures of different Sizes One hundred and twenty Six all of Great Masters and Gold Frames. There is a Printed Book which tells who are the Masters that Painted all these pictures." ${ }^{34}$ Interestingly, while the Duchess (who was admittedly quite elderly and dictating from memory) failed to mention the maker of these paintings, she took care to emphasize that they documented a collection of works by "Great Masters." It is intriguing to imagine that the Marlboroughs might have perceived a parallel between Teniers's painted copies of Italian works in the archducal collection, and the lavish publication which resulted, and Lens's limned copies after some of the principal works in their own rapidly expanding collection. ${ }^{3}$

The Marlboroughs' collection was, crucially, not an inherited collection but one which they themselves had assembled, an ambitious endeavor only made possible by the duke's military and diplomatic successes and the duchess's clever exploitation of her role as the queen's close friend and confidante. Many of the paintings copied by Lens had been acquired by the duke on the Continent during the period of his greatest military and diplomatic successes, some by purchase, but 
others given (willingly or unwillingly) by local governments as tribute to the heroic commander. ${ }^{36}$ Others had similarly prestigious provenances. ${ }^{37}$ Reproducing them in miniature was a way of magnifying their significance and that of their owners. The specific choice of medium-gouache or watercolor on vellum - was typically and traditionally English, giving the copies a distinctive appearance quite different from Teniers's copies, or indeed from the original oil paintings. The seventeenth-century miniature painter and theorist Edward Norgate spoke of Peter Oliver's smallscale copies after Titian (painted, like Lens's copies, in watercolor or gouache on vellum) as having the originals "translated into English Lymning." ${ }^{38}$ Although there is no way of knowing whether the Marlboroughs - or indeed any other of Lens's patrons-would have made the same association, it is intriguing to consider the copies as a way of imposing a nationalistic stamp on paintings gathered from other countries.

Typically, such valuable miniatures and small paintings were kept in rooms designed for intimate viewing, such as private cabinets or dressing rooms, and often in chambers belonging to women: at Blenheim, Teniers's pasticci were displayed in a room adjacent to the Duchess of Marlborough's dressing room, and cabinet miniatures by Lens might have been kept there as well. In describing the work of one of Lens's pupils, Catherine da Costa, Vertue noted that the cabinet miniatures she had made-many apparently copies after Lens's miniatures_-all these furnishes a Room ... which makes a very grand Collection. for a Ladys Cabinet." ${ }^{39}$ In 1749 Vertue recorded a number of cabinet miniatures made by Joseph Goupy after works by Titian, Guido Reni, Raphael, and others for Frederick, Prince of Wales, as hanging in Princess Augusta's dressing room at Leicester House. ${ }^{40}$ The only one of Lens's works specifically mentioned by the Duchess of Marlborough is the portrait of the duke based on van Dyck's Portrait of Charles I on Horseback, which was described in the codicil to her will (1744) as being then at Windsor Lodge, the duchess's residence in Windsor Great Park, with no further information as to its display. ${ }^{41}$

14 This consideration of one small painting in the collection of the Metropolitan Museum has perhaps raised more questions than it has answered. A further search of documents in the Blenheim archives may turn up additional information concerning the Marlboroughs' relationship with Bernard Lens during the 1720s, although that seems unlikely. It is far more certain that cabinet miniatures by Lens reproducing works by Rubens, van Dyck, and other Old Masters will continue to resurface in public and private collections and at auction. Coupled with Lens's habit of providing his miniatures with extensive inscriptions and precise dates, this may one day enable the entire story of Lens's copy after Rubens's magnificent portrait Rubens, His Wife Helena, and Their Son Frans to be told with a command of detail worthy of Walter's memory.

Betsy Wieseman is the Paul J. and Edith Ingalls Vignos, Jr. Curator of European Painting and Sculpture 1500-1800 at the Cleveland Museum of Art. She studied art history at the University of Delaware and received a PhD from Columbia University with a thesis on the Dutch painter Caspar Netscher. Prior to joining the CMA in 2017, she held positions at the National Gallery, London, the Cincinnati Art Museum, the Allen Memorial Art Museum, Oberlin College, and the Museum of Fine Arts, Boston. Recent projects include exhibitions on Vermeer and his contemporaries (Vermeer's Women, 2011; and Vermeer and Music, 2013), as well as Rembrandt: The Late Works (2014), a collaboration between the National Gallery and the Rijksmuseum, Amsterdam. Current 
research interests include the representation of material culture in Dutch genre painting and the collecting of Dutch paintings in England in the early nineteenth century.

BWieseman@clevelandart.org

\section{List of Illustrations}

Fig. 1 Bernard Lens III, Rubens, His Wife Helena Fourment, and Their Son Frans, 1721, watercolor and bodycolor on vellum, 394 x $302 \mathrm{~mm}$. New York, The Metropolitan Museum of Art, inv. 1984.442 (artwork in the public domain)

Fig. 2 Peter Paul Rubens, Rubens, His Wife Helena Fourment, and Their Son Frans, ca. 1635, oil on wood, 203.8 x $158.1 \mathrm{~cm}$. New York, The Metropolitan Museum of Art, inv. 1981.238 (artwork in the public domain)

Fig. 3 Bernard Lens III, The Victorious Hero Takes Occasion to Conclude Peace, 1720, watercolor and gouache, heightened with gold, on vellum, 394 x $476 \mathrm{~mm}$. New Haven, Yale Center for British Art, inv. B1982.6 (artwork in the public domain)

Fig. 4 Bernard Lens III, King Charles I on Horseback, 1721, gouache on vellum, 483 x 413 mm. Croft Castle, Herefordshire, Midlands (National Trust), inv. NT 537591 (artwork in the public domain)

Fig. 5 Anthony van Dyck, King Charles I on Horseback, ca. 1638, oil on canvas, approx. 367 x 292.1 $\mathrm{cm}$. London, The National Gallery, inv. NG1172 (artwork in the public domain)

Fig. 6 Bernard Lens III, Sarah Churchill, Duchess of Marlborough, 1720, watercolor on vellum, approx. 405 x $260 \mathrm{~mm}$. London, Victoria and Albert Museum, inv. 627-1882 (artwork in the public domain)

${ }^{1}$ Graham Reynolds and Katherine Baetjer, European Miniatures in the Metropolitan Museum of Art (New York: The Metropolitan Museum of Art, 1996), 126. When the painting was sold at London (Sotheby's, July 7, 1983, lot 96), it had a label attached to the backboard with the inscription: Rubens and his Wife and Child / Copied from the Original of Rubens / in the cabinet of his Grace the duke of Marlborough at Blenheim / Castle Bernard Lens / Painter in Miniature to his Majesty / Anno Domini 1721 with leave of / his Grace / No. 55, but this label is no longer visible.

${ }^{2}$ Ann-Marie Logan, "Bernard Lens and the Marlborough Collection," in Essays in Honor of Paul Mellon, Collector and Benefactor, ed. John Wilmerding, (Washington, D.C.: Olympic, 1986), 203-15.

${ }^{3}$ Letter dated November 8, 1706; Private Correspondence of Sarah, Duchess of Marlborough..., 
(London, 1838), 1:58-59. There is little written on the collecting activities of the first Duke and Duchess of Marlborough; I am enormously grateful to Francis Russell for sharing his vast knowledge and a recent essay on the topic.

${ }^{4}$ The most up-to-date source of biographical information on the Lens family is Katherine Coombs, "Lens family (per. c.1650-1779)," Oxford Dictionary of National Biography (Oxford: Oxford University Press, 2004; online ed., January 2008, http://www.oxforddnb.com/view/article/66537 (accessed December 14, 2015).

${ }^{5}$ For Lens's lessons to Spencer: British Library, Blenheim Papers, vol. CCCXLV (Add. Ms. 61445), fol. 101. He also taught miniature painting to such talented amateurs as Catherine da Costa and Sarah Stanley, the daughter of Sir Hans Sloane.

${ }^{6}$ See John Murdoch, Jim Murrell, Patrick J. Noon, and Roy Strong, The English Miniature (New Haven and London: Yale University Press, 1981), 63, 156-57.

7 Jane Roberts, "The Limnings, Drawings and Prints in Charles I's Collection," in The Late King's Goods, ed. Arthur MacGregor (London and Oxford: Oxford University Press, 1989), 117-19.

${ }^{8}$ In the case of Lens, Rubens, His Wife Hélène Fourment, and Their Son Frans at least exists in another (unsigned) version, with minor differences: watercolor and gouache on paper, 380 x 303 $\mathrm{mm}$; private collection, England (2001), said to be dated 1717 on the verso. Photo RKD. The catalogue of the 1737 sale of Lens's collection includes approximately sixty copies after paintings by other artists, many of which can be identified with extant miniatures by Lens: sale, Bernard Lens, London, Christopher Cock, February 11-20, 1737 (Lugt 468a). I am indebted to Jonny Yarker for drawing my attention to this essential reference. Several of the copies appear to have remained in the possession of the Lens family and reappear as the property of Lens's son, Andrew Benjamin Lens: his sale, London, Langford, April 16, 1777 (Lugt 2656).

${ }^{9}$ Six of these are in the collection of the Victoria and Albert Museum, London (inv. E.594-1994 to E.599-1994).

${ }^{10}$ In 1721 John Hervey, Earl of Bristol, bought a series of artists' portraits from Lens: "1721. - July 26. Paid Mr. Bernard Lens ye limner in full for six pictures of Vandyke, Sam Cooper, Sir Peter Lely, Greenhill, Dobson, \& Sir Isaac Newton, 18 guineas"; see The Diary of John Hervey, First Earl of Bristol, With Extracts from His Book of Expenses, 1688 to 1742, ed. S. A. H. Hervey (Wells, 1894), 162.

${ }^{11}$ Horace Walpole, Anecdotes of Painting in England, 3rd ed. (London, 1786), 4: 201. Lens made at least three copies after paintings in the collection of Walpole's father, Sir Robert Walpole; see sale, Bernard Lens, London, Christopher Cock, February 11, 1737, lots 33, 35 and 50.

${ }^{12}$ On Goupy, see Bruce Robertson and Robert Dance, "Joseph Goupy and the Art of the Copy," Bulletin of the Cleveland Museum of Art 75 (1988): 354-75.

${ }^{13}$ Logan, "Bernard Lens," 204.

${ }^{14}$ Lens popularized the so-called "Lens frame," a simple molded frame of pear wood stained black.

${ }^{15}$ Lens's copy of the last, inscribed and dated September 21, 1728, is in the Yale Center for British Art, New Haven (gouache on vellum, wrapped around panel, 285 x $460 \mathrm{~mm}$, inv. B1998.9.2); the original, dated 1567, is in the Royal Collection (inv. RCIN 401230), and a second large-scale version of the composition is at Goodwood House, near Chichester. The commission is mentioned by George Vertue: "Vertue's Note Book A.g. [British Museum Add. MS. 23,070]," Volume of the Walpole Society 20 (1931-32): 58-59. The half-length portrait of Prior cost 20 guineas; see Richard W. Goulding, "The Welbeck Abbey Miniatures," Volume of the Walpole Society 4 (1914-15): 
41. More generally on Lens's relationship with the Harley family, see Kim Sloan, 'A Noble Art': Amateur Artists and Drawing Masters c. 1600-1800, exh. cat. (London: British Museum, 2000), 114-15.

${ }^{16}$ See Diary of John Hervey, 161-62. The original, by a provincial follower of Raphael, possibly seventeenth century, was displayed at Kensington Palace and later removed to Hampton Court (inv. RCIN 402872).

${ }^{17}$ In a letter to Kneller dated December 7, 1713, Chandos wrote: "I have sent to Mr Lence [Lens] for ye Pictures he has made from ye family piece" (Huntington Library, Manuscripts Department, Stowe Papers, inv. ST 57, vol. 9, fol. 281; cited in Susan Jenkins, Portrait of a Patron: The Patronage and Collecting of James Brydges, 1st Duke of Chandos (1674-1744) (Aldershot: Ashgate, 2007), 141 n54. Kneller's original portrait, dated 1713, is in the National Gallery of Canada, Ottawa (inv. 4295).

${ }^{18}$ Gouache on paper, 380 x 300 mm; with Lowell Libson \& Jonny Yarker, Ltd., London (2018). See Richard Stephens and Jonny Yarker, The Spirit and Force of Art: Drawing in Britain 1600-1750 (London, Lowell Libson \& Jonny Yarker, Ltd., 2018), 138-39; and Jonny Yarker, "A Little-known Auction Catalogue and Some New Light on Bernard Lens III (1682-1740)," published online at http://libson-yarker.com/news-and-events/news/a-little-known-auction-catalogue-and-somenew-light-on-bernard-lens-iii-168. Poussin's original of ca. 1636-37 is at Stourhead, Wiltshire (inv. NT 732103).

${ }^{19}$ Sale, Bernard Lens, London, Christopher Cock, February 11, 1737, lot 23: "Hercules between Virtue and Pleasure, after Poussin, in the Collection of his Grace the Duke of Chandon [sic]."

${ }^{20}$ A second small-scale copy after Rubens's The Victorious Hero Takes Occasion to Conclude Peace (see below), signed by Lens's pupil Catherine da Costa and dated December 5, 1723, was presumably done from Lens's miniature (395 x 490 mm; sale, Melbourne, Mosgreen Auctions, June 29, 2015, lot 905, described as a "hand coloured engraving"). Vertue notes that da Costa "Coppyd many pictutes \& limnings mostly all the remarkable pictures of Fame in England by Rubens Vandyke \& other masters, which Mr. Lens her instructor had coppyd"; see "Vertue's Note Book B. 4 [British Museum Add. MS 23,079]," Volume of the Walpole Society 22 (1933-34): 115.

${ }^{21}$ For example, a Portrait of John Churchill in Armor, sale, London, Bonham's, November 20, 1997, lot 18 (as ca. 1714-15). Among the dowager duchess's accounts is Lens's bill for giving drawing lessons to her grandson, John Churchill, in 1723-24 (British Library, Blenheim Papers, vol. CCCXLV [Add. Ms. 61445], fol. 101).

${ }^{22}$ Rubens's original is lost; the composition survives in a workshop version (oil on canvas, $230 \mathrm{x}$ $273 \mathrm{~cm}$; Siegen, Westphalia, Museum des Siegerlandes, inv. No. R205). See Logan, "Bernard Lens," esp. 206-10.

${ }^{23}$ Including portraits of Mary Churchill, Duchess of Montague and (possibly) Henrietta Churchill, Countess of Godolphin; both in the collection of the Duke of Buccleuch.

${ }^{24}$ The portrait of Anne, Countess of Sunderland, with her son was in the collection of the Duke of Marlborough in 1934 (watercolor on ivory, $143 \times 121 \mathrm{~mm}$ ).

${ }^{25}$ Lens's portrait of Charles (b. 1706), John (b. 1708), and Diana (b. 1710) Spencer is at Althorp. A more faithful copy by Lens after van Dyck's painting, dated 1719, is in the Duke of Devonshire collection at Chatsworth.

${ }^{26}$ The miniature of the duke was in the collection of the Duke of Brownlow in 1934.

${ }^{27}$ Watercolor on vellum, $270 \mathrm{~mm}$ high; sale, London, Bonham's, May 21, 2008, lot 23. Lens's copy of Rubens, His Wife Helena Fourment, and Their Son Frans may have carried a similar inscription 
(see note 1). The version of van Dyck's composition owned by the Marlboroughs is in the Walters Art Museum, Baltimore (inv. 37.234). There is no copy by Lens of this description listed in the 1737 auction catalogue.

${ }^{28}$ Gouache on vellum, 350 x 215 mm; sale, Paris, Drouot, November 26, 1998, lot 26. On Veronese's original, now in the National Gallery, London (inv. NG1041), and the question of whether that painting had been in the Marlborough collection, see Nicholas Penny, National Gallery Catalogues: The Sixteenth Century Italian Schools, Vol. II: Venice 1540-1600 (London: The National Gallery, 2008), 392. There is no copy by Lens of this description listed in the 1737 auction catalogue.

${ }^{29}$ Gouache on vellum, 287 x 346 mm; sale, London, Sotheby's, December 10, 1979, lot 361. Lens's copy is listed as lot 55 ("The Roman Charity, after a Capital Picture of Rubens in the Cabinet of her Grace the Duchess of Marlborough at Blenheim") in the 1737 auction catalogue. For Rubens's original: Peter Paul Rubens, Roman Charity, mid-1630s, oil on canvas, 194 x $200 \mathrm{~cm}$ (including a strip of approx. $25 \mathrm{~cm}$ at the top, added later); Siegen, Museum des Siegerlandes, inv. 3 F 1955; see Elizabeth McGrath, Corpus Rubenianum Ludwig Burchard, Part 13, Subjects from History (London: Harvey Miller, 1997), 2:110-13, no. 22.

30 "Vertue's Note Book A.b.," Volume of the Walpole Society 18 (1929-30): 119. While Lens's copy after Rubens's Three Graces is possibly to be identified with lot 26 ("The Graces unveiling Nature, after a Capital Picture of Rubens") in the 1737 auction catalogue, there is no painting in the catalogue that can be identified as a copy after van Dyck's Time Clipping Cupid's Wings.

${ }^{31}$ On Teniers's copies, see Ernst Vegelin van Claerbergen, ed., David Teniers and the Theatre of Painting, exh. cat. (London: Courtauld Institute of Art Gallery, 2006); and in the same catalogue, specifically on the history of the copies, James Methuen-Campbell, "Early Collections of Teniers's Copies for the Theatrum Pictorium," 59-63. Teniers's small paintings were dispersed in the Marlborough sale in 1886.

${ }^{32}$ Hans Vlieghe, David Teniers the Younger (1610-1690): A Biography (Turnhout: Brepols, 2011), 39.

${ }^{33}$ Pierre Jacques Fougeroux, “Voiage D’Angleterre D’Hollande et de Flandre fait en Lannée 1728” (London, National Art Library, MSL/1912/1255), fol. 110.

${ }^{34}$ See Tessa Murdoch, "Blenheim Palace, Oxfordshire, and Marlborough House, London 1740," in Noble Households: Eighteenth-Century Inventories of Great English Houses; A Tribute to John Cornforth, ed. Tessa Murdoch (Cambridge: John Adamson, 2006), 276. The original manuscript is in the British Library.

35 The surviving copies Lens made for the Marlboroughs depict exclusively Flemish paintings, offering a fascinating (if unintended) complement to the Italian focus of the copies Teniers made for the archduke.

${ }^{36}$ Rubens, His Wife Helena Fourment, and Their Son Frans was a gift from the city of Brussels, and Marlborough specifically requested van Dyck's Charles I on Horseback (formerly in the English royal collection) as a gift from Emperor Joseph I.

${ }^{37}$ Rubens's Roman Charity was purchased by the duchess from the Duke of Portland's sale; Anthony van Dyck's Time Clipping Cupid's Wings, previously owned by King William III, was purchased by a consortium which included James Brydges, Duke of Chandos, who in turn gave the painting to Marlborough.

${ }^{38}$ Edward Norgate, Miniatura or the Art of Limning, edited, introduced, and annotated by Jeffrey M. Muller and Jim Murrell (New Haven and London: Yale Center for British Art, 1997), 89. 
39 “Vertue’s Note Book B. 4," 115.

${ }^{40}$ Kimerly Rorschach, "Frederick, Prince of Wales (1707-51) as Collector and Patron," Volume of the Walpole Society 55 (1989-90): 18, 72-74.

${ }^{41}$ The codicil to the duchess's will states: "I give to my granddaughter Mary Duchess of Leeds . . the Picture in Water-Colours of the late Duke of Marlborough on Horseback, drawn by Lens, which is now at WindsorLodge" (A true copy of the last will and testament of Her Grace Sarah, late duchess dowager of Marlborough: with the Codicil thereto annexed [London, 1744], 71-20). Lens's miniature was estimated at $£ 42$ in a valuation of the duchess's jewelry drawn up in 1734; British Library, Blenheim Papers, vol. CCCXXXVII (Add. Ms. 61438), fol. 110.

\section{Bibliography}

Claerbergen, Ernst Vegelin van, ed. David Teniers and the Theatre of Painting. Exh. cat. London: Courtauld Institute of Art Gallery, 2006.

Coombs, Katherine. "Lens family (per. c.1650-1779)." Oxford Dictionary of National Biography. Oxford: Oxford University Press, 2004; online edition, January 2008 http://www.oxforddnb. com/view/article/66537.

Goulding, Richard W. "The Welbeck Abbey Miniatures." Volume of the Walpole Society 4 (1914-15): 1-224.

Jenkins, Susan. Portrait of a Patron: The Patronage and Collecting of James Brydges, 1st Duke of Chandos (1674-1744). Aldershot: Ashgate, 2007.

McGrath, Elizabeth. Corpus Rubenianum Ludwig Burchard. Part 13, Subjects from History. 2 vols. London: Harvey Miller, 1997.

Marlborough, Sarah Jenyns Churchill. Private Correspondence of Sarah, Duchess of Marlborough: Illustrative of the Court and Times of Queen Anne; with Her Sketches and Opinions of Her Contemporaries, and the Select Correspondence of Her Husband, John, Duke of Marlborough. 2 vols. London, 1838.

Methuen-Campbell, James. "Early Collections of Teniers's Copies for the Theatrum Pictorium." In David Teniers and the Theatre of Painting, exh. cat., edited by Ernst Vegelin van Claerbergen, 59-63. London: Courtauld Institute of Art Gallery, 2006.

Murdoch, John, Jim Murrell, Patrick J. Noon, and Roy Strong. The English Miniature. New Haven and London: Yale University Press, 1981.

Murdoch, Tessa. "Blenheim Palace, Oxfordshire, and Marlborough House, London 1740." In Noble Households: Eighteenth-Century Inventories of Great English Houses; A Tribute to John 
Cornforth, edited by Tessa Murdoch, 273-87. Cambridge: John Adamson, 2006.

Norgate, Edward. Miniatura or the Art of Limning. Edited, introduced, and annotated by Jeffrey M. Muller and Jim Murrell. New Haven and London: Yale Center for British Art, 1997.

Penny, Nicholas. National Gallery Catalogues: The Sixteenth Century Italian Schools, Vol. II: Venice 1540-1600. London: The National Gallery, 2008.

Reynolds, Graham, and Katherine Baetjer. European Miniatures in The Metropolitan Museum of Art. New York: The Metropolitan Museum of Art, 1996.

Roberts, Jane. “The Limnings, Drawings and Prints in Charles I's Collection.” In The Late King's Goods, edited by Arthur MacGregor, 115-29. London and Oxford: Oxford University Press, 1989.

Robertson, Bruce, and Robert Dance. "Joseph Goupy and the Art of the Copy." Bulletin of the Cleveland Museum of Art 75 (1988): 354-75.

Rorschach, Kimerly. "Frederick, Prince of Wales (1707-51) as Collector and Patron." Volume of the Walpole Society 55 (1989-90): 1-56.

Sloan, Kim. 'A Noble Art': Amateur Artists and Drawing Masters c. 1600-1800. Exh. cat. London: British Museum, 2000.

Stephens, Richard, and Jonny Yarker. The Spirit and Force of Art: Drawing in Britain 16001750. Exh. cat. London: Lowell Libson \& Jonny Yarker, Ltd., 2018.

A true copy of the last will and testament of Her Grace Sarah, late duchess dowager of Marlborough: with the Codicil thereto annexed. London, 1744.

Vertue, George. "Vertue's Note Book A.b. [British Museum Add. MS. 23,069]." Volume of the Walpole Society 18 (1929): 81-161.

. "Vertue's Note Book A.g. [British Museum Add. MS. 23,070]." Volume of the Walpole Society 20 (1931): 1-93.

. "Vertue's Note Book B. 4 [British Museum Add. MS. 23,079]." Volume of the Walpole Society 22 (1933): 87-142.

. "Vertue's Note Book A.x. [British Museum Add. MS. 23,072]." Volume of the Walpole Society 24 (1935): 101-97.

Vlieghe, Hans. David Teniers the Younger (1610-1690): A Biography. Turnhout: Brepols, 2011.

Walpole, Horace. Anecdotes of Painting in England. . . 3rd ed. 5 vols. London, 1786.

JHNA 10:2 (Summer 2018) 
Yarker, Jonny. "A Little-known Auction Catalogue and Some New Light on Bernard Lens III (1682-1740)." Published online at http://libson-yarker.com/news-and-events/news/a-littleknown-auction-catalogue-and-some-new-light-on-bernard-lens-iii-168.

\section{Unpublished Sources}

Blenheim Papers, vol. CCCXXXVIII (London, British Library, Add. Ms. 61438).

Blenheim Papers, vol. CCCXLV (London, British Library, Add. Ms. 61445).

Fougeroux, Pierre Jacques. Voiage D'Angleterre D'Hollande et de Flandre fait en L'année 1728 (London, National Art Library, MSL/1912/1255)

Recommended Citation:

Marjorie E. Wieseman, "Protected: Bernard Lens's Miniatures for the Duke and Duchess of Marlborough," Journal of Historians of Netherlandish Art 10:2 (Summer 2018) D0l: 10.5092/jhna.2018.10.2.3 